\title{
WYCHOWANIE MORALNE W KONTEKŚCIE PRZEMIAN CYWILIZACYJNYCH
}

Każda edukacja, także religijna, odbywa się w konkretnych uwarunkowaniach. Nie może przeto być prowadzona bez uwzględnienia szerszego kontekstu społecznego. Problematykę edukacji religijnej w sposób uporządkowany i systematyczny podejmuje się dziś w ramach pedagogiki religii. Coraz wyraźniej uświadamiamy sobie potrzebę takiej refleksji.

Wielowymiarowe przekształcanie ludzkiego życia przez cywilizację przemysłową zapoczątkowało proces rozwoju nowej kultury. $\mathrm{U}$ jej podstaw tkwi liberalizm, postrzegany nie tylko jako system gospodarczy, ale i postawa światopoglądowa, z określoną wizją ludzkiej natury i koncepcją życia społecznego. Nurt ten podkreślał pełne urzeczywistnienie się człowieka w jego indywidualnej wolności. W przeciwieństwie do tej koncepcji, charakterystycznej dla cywilizacji Zachodu, Wschód próbował realizować pełnię człowieczeństwa w zbiorowości i przez zbiorowość, w którą pojedyncza osoba jest całkowicie i bez reszty wtopiona. ${ }^{1}$

Obie te koncepcje: skrajnie liberalna, indywidualistyczna oraz kolektywistyczna, przechodziły różne stadia rozwoju. Wiek XX stał się świadkiem bankructwa w gospodarce zarówno skrajnego indywidualizmu, jak i koncepcji kolektywistycznej. Początek nowego stulecia, mimo przemian, jakie zaszły w obrazie społeczno-ekonomicznym świata, nie jest wolny od zagrożeń wynikających z podziału świata na bogatych, dotkniętych postawą konsumpcjonistyczną, i biednych, cierpiących z różnego powodu upośledzeń.

1 Por. K. B ro c k mö 11 e r, Cywilizacja przemysłowa i religia, Paryż 1974, s. 29. 
Jan Paweł II podczas jednej z pielgrzymek do Meksyku, wskazując na gospodarcze osiągnięcia współczesności, ostrzegał przed przedmiotowym traktowaniem człowieka wprzęgniętego w mechanizmy gospodarki rynkowej. ${ }^{2}$ Stopień zróżnicowania posiadanych dóbr i sposobu ich dystrybucji sprawia, że przepaść między biednymi i bogatymi ciągle się dziś powiększa.

\section{Kontekst kulturowy i eklezjalny współczesnego wychowania moralnego}

Przemiany współczesnego świata, bardzo widoczne zwłaszcza w dziedzinie postępu technicznego, nie ograniczają się do wymiaru ekonomicznego, ale prowadzą do przemian we wszystkich niemal innych wymiarach życia. Upadek systemu komunistycznego u schyłku XX w., rozwój różnych form organizacji międzynarodowych, szybki postęp techniczny, a zwłaszcza niezwykłe osiągnięcia w dziedzinie komunikacji - to wszystko sprawiło, że współczesność znalazła się niejako u progu nowego jakościowo obszaru cywilizacyjnego i kulturowego.

Mamy zatem zjawisko postępującej dowolności stylu życia. Szczególne znaczenie dla teorii i praktyki wychowawczej ma pluralizm kulturowy i społeczny. Pluralizm kulturowy jest to sytuacja, w której występuje konkurencja w zakresie preferowania różnych światopoglądów, stylów uprawiania literatury, sztuki i pozyskiwania dla nich klientów na rynku światopoglądowym. Chodzi tu o rywalizację dotyczącą światopoglądów, filozofii życia i systemów znaczeń. Rozumie się przez nie systemy poglądów, które obejmują wszelkie doświadczenia człowieka i wszystkie zakresy jego aktywności oraz nadają im całościowy sens. ${ }^{3}$

2 Por. Ja n P aw e 1 II, Przemówienie w Izamal podczas apostolskiej podróży do Meksyku, OsRomPol 11/1993, s. 15.

3 Por. W. P i w o w a r s k i, Pluralizm społeczno-kulturowy a religia, Roczniki Nauk Społecznych 8/1980, s. 113; B. D r o ż d ż, Wychowawcza funkcja Kościoła w społeczeństwie pluralistycznym, Legnica 1997, s. 18. 


\section{Pluralizm społeczno-kulturowy}

Pluralizm społeczny można określić jako „sytuację, w której jednostki ludzkie, grupy i instytucje społeczne ze względu na segmentaryzację, autonomizację i specjalizację społeczeństwa pozostają we wzajemnej konkurencji i współzawodnictwie w preferowaniu, legitymizowaniu i urzeczywistnianiu własnych systemów znaczeń" ${ }^{4}$ Zdrowe życie społeczne wymaga istnienia i działania całej hierarchii społeczności, które nie tylko konkurują ze sobą, ale są sobie wzajemnie niezbędne do osiągnięcia celów każdej z nich. Gwarancją ich istnienia i względnej stabilności jest respektowanie zasady pomocniczości oraz zasady wspólnego dobra. ${ }^{5}$

Tak widziany pluralizm jest zjawiskiem normalnym i nieodwracalnym. Społeczeństwa zawsze były w jakimś sensie pluralistyczne, ale nigdy dotąd pluralizm ten nie był tak wielowarstwowy i różnorodny. Przynosi on wiele nowych zjawisk i skutków, szczególnie dla życia społeczno-moralnego społeczeństwa i jednostki. Ze współczesnym pluralistycznym społeczeństwem, obok wielu nowych możliwości rozwoju jednostki, związane są także różnorakie zagrożenia. Chodzi zwłaszcza o przyjęcie hedonistycznej wizji życia, o dążenie do uczynienia z dążenia do sukcesu za wszelką cenę podstawowego imperatywu działania człowieka. U współczesnego człowieka prowadzi to wielokrotnie do rezygnacji z troski o własną godność. Przyczynę tego stanu rzeczy należy upatrywać w zaniku świadomości Boga i w kryzysie sumienia współczesnego człowieka. W imię fałszywie rozumianej demokracji niekiedy rezygnuje się ze stosowania norm etycznych w życiu publicznym. Procesami znamiennymi dla pluralizmu społeczno-kulturowego są: upowszechnianie się zjawiska ateizmu oraz sekularyzacja, które ujawniają się w społeczeństwach

4 W. P i w ow a r s k i, Pluralizm społeczno-kulturowy a religia, s. 109; por. także R. K a m i ń s k i, Duszpasterstwo Kościołów w społeczeństwie pluralistycznym, Lublin 1997, s. 17-26.

5 Por. B. D ro ż d ż, Wychowawcza funkcja Kościoła w społeczeństwie pluralistycznym, s. 39. 
o charakterze konsumpcyjnym, $\mathrm{z}$ charakterystycznym dla nich relatywizmem etycznym. ${ }^{6}$

Postępujący w niespotykanym dotąd w historii tempie rozwój możliwości komunikacji, szczególnie przydatny w integrujących się współczesnych społeczeństwach, wprowadza zjawisko coraz bardziej postępującej globalizacji, która wyraża się swobodnym przepływem kapitałów, dóbr i usług. Jest to nowe i ważne dla przyszłości zjawisko. Dotyczy ono nie tylko sfery ekonomicznej, choć tu jest najbardziej widoczne, ale zaczyna także stawać się zjawiskiem społecznym i kulturowym. Zarówno w sferze ekonomicznej, jak i kulturowej może ułatwiać przepływ kapitału i siły roboczej, swobodną wymianę gospodarczą i przyczyniać się do wzrostu dobrobytu społeczeństw. Powiązania ekonomiczne odległych części świata istniały zawsze, jednak w ostatnich dwóch dekadach stały się szczególnie silne. Jednak globalizacja niesie z sobą także zagrożenia. Przemiany globalizacji będą przyspieszać tempo przemian w świecie, ale nie wszyscy ludzie będą mogli się do nich przystosować, a nawet je zrozumieć. Nie wszystkie bowiem regiony czy kraje mogą sprostać wyścigowi i konkurencyjności, które ona przynosi. Tam, gdzie nie będzie właściwego przygotowania ludzi, zwłaszcza przez dostosowanie systemów edukacyjnych do globalizującej się ekonomii, może dojść nawet do „załamania społecznego z wszystkimi negatywnymi, wręcz dramatycznymi, konsekwencjami, które mogą z tego wyniknąć". Globali-

6 Por. J a n P a w e 1 II, Przemówienie na spotkaniu z Konferencją Episkopatu Austrii w Salzburgu (24 VI 1988), OsRomPol 7/1988, s. 25; t e n ż e, Przemówienie na spotkaniu z prezydentem Republiki Federalnej Niemiec i innymi władzami, w: E. W e ro n, A. Jaroch (red.), Dzieła wszystkie. Nauczanie papieskie Jana Pawła II, Poznań-Warszawa 1985, s. 626-627; t e n ż e, Przemówienie do uczestników plenarnego zebrania Sekretariatu dla Niewierzacych (5 III 1988), OsRomPol 3-4/1988, s. 28.

7 Zob. L.J. J a s iń s k i, Pytania czasu globalizacji, Przegląd Powszechny 116(1999) nr 10, s. 3-40; por. P. K o e p f, Globalisierung, München 1998, s. 31.

8 Kom is a Europej s ka, Biała Księga Kształcenia i Doskonalenia. Nauczanie i uczenie się. Na drodze do uczacego się społeczeństwa, Warszawa 1997, s. 23-24. 
zacja może prowadzić do marginalizacji całych społeczeństw, które za tymi procesami nie nadążą; pojawi się wtedy zjawisko bezrobocia na dużą skalę, szczególnie dotykając młode pokolenie biednych regionów świata. ${ }^{9}$

Innym zjawiskiem, które wydaje się charakterystyczne dla współczesności, jest zdominowanie społeczeństwa przez „kulturę wizualną". Żyjemy - jak twierdził E. Morin - w dobie industrializacji ducha, który pragnie przeniknąć wnętrze człowieka i tworzy nową kulturę, zrodzoną z prasy, radia, kina i telewizji. Socjologowie nazwali ją kulturą masową (mass-culture) ${ }^{10}$ Kultura ta zdobyła sobie miano kultury konsumpcyjnej, zrodzonej z dobrobytu, jaki zapewniła wielu ludziom cywilizacja techniczna. Środki społecznego przekazu, które ona stworzyła, stały się w rękach potentatów ekonomicznych sposobem urabiania opinii, a zarazem narzędziem manipulacji ludźmi. Komercjalni nadawcy informacji, atakując nieustannie odbiorców, czynią z nich masowych konsumentów dóbr materialnych i kulturalnych. To rozwój ekonomiczny umożliwił prawdziwą eksplozję środków społecznego przekazu, które wypełniły wolny czas współczesnego człowieka, jednocześnie czyniąc go biernym odbiorcą zaplanowanego standardu życia. W efekcie coraz agresywniejszej i coraz lepiej podanej informacji powstaje typ kultury mozaikowej, w której nie zdobywa się już wiedzy o świecie w sposób racjonalny i progresywny, ale z reguły fragmentaryczny, a często powierzchowny.

Refleksja nad sytuacją społeczeństwa w dobie tak gwałtownych przemian nie jest jednorodna. Obok tych, którzy w rozwoju nauk ścisłych i cywilizacji technicznej dopatrywali się dehumanizacji człowieka, skierowania jego uwagi na wartości materialne i pewnej pogardy dla wartości duchowych, byli inni, którzy widzieli w tym

9 Zjawisko globalizacji prezentuje obszernie: M. A. P e e t e r s, Globalizacja zachodniej rewolucji kulturowej, Warszawa 2010.

10 Por. E. M or i n, Duch czasu, Kraków 1965, s. 9n.; A. Kł o s k o w s k a, Kultura masowa, Warszawa 1980, s. 94-106; por. L. W it k o w s k i, Edukacja wobec sporów o (po)nowoczesność, Warszawa 1998, s. 119. 
wyraz nowych dążeń ludzkości. Zdając sobie sprawę z przełomowego znaczenia zachodzących przemian i z niebezpieczeństwa przytłoczenia wartości osobowych przez nadmierną racjonalizację i technizację kultury, domagali się nowego ujęcia stosunku człowieka do otaczającego go świata. Wskazywano więc, że technika może być cennym składnikiem nowego humanizmu. ${ }^{11}$ Słabnie także dawna konfrontacja myśli technicznej i religijnej, a dochodzi do głosu coraz wyraźniej opinia, że sprzeczność między nauką a wiarą jest tylko pozorna. ${ }^{12}$

\section{Sobór Watykański o zmieniającym się świecie}

Jednocześnie jednak wskazuje się, że nowa sytuacja kulturowa, zmieniając głęboko ludzką psychikę, domaga się nowych ujęć i motywacji $\mathrm{w}$ dziedzinie moralno-religijnej. ${ }^{13}$ Skutki dokonujących się przemian społeczno-kulturowych nie są jednoznaczne ani nawet jednokierunkowe. Zwrócili na to uwagę uczestnicy II Soboru Watykańskiego, kiedy w konstytucji Gaudium et spes stwierdzili, że nowe warunki wywierają wpływ i na samo życie religijne. $Z$ jednej strony zdolność krytyczniejszego osądu oczyszcza je z magicznego pojmowania świata i błąkających się jeszcze zabobonów oraz wymaga coraz bardziej osobowego i czynnego przylgnięcia do wiary, dzięki czemu wielu dochodzi do żywszego poczucia Boga; z drugiej zaś strony liczniejsze masy praktycznie odchodzą od religii. Zachodzące przemiany nie muszą więc prowadzić do zaniku religijności, choć wywierają wpływ na jej profil zarówno ilościowy, jak i jakościowy. ${ }^{14}$

1 Por. B. P r z y b y 1 s k i, Znaki czasu, AK 74/1970, s. 135-136.

12 Zob. Ja n P a w e $\nmid$ II, „Fides et ratio”. Encyklika o relacjach między wiara a rozumem (1998), w: Encykliki Ojca Świętego Jana Pawła II, Kraków 2000, s. 1081-1198 (dalej: FR).

13 Por. P. To m a s i k, Nauczanie religii w publicznym liceum ogólnokształcącym wobec założé programowych polskiej szkoły, Warszawa 1998, s. 395n.

14 Por. S o bó r W a t y k án s k i II, Konstytucja duszpasterska o Kościele w świecie współczesnym „,Gaudium et spes”, w: M. P r z y b ył (tłum.), Sobór Watykański II. Konstytucje, dekrety, deklaracje, Poznań 2002, nr 7 (dalej: GS). 
Kluczowym pojęciem do opisywania współczesności jest pojęcie postmodernizmu. ${ }^{15}$ Jest to zjawisko kulturowe obejmujące sztukę, filozofię, naukę i politykę, a także i pedagogikę. ${ }^{16} \mathrm{O}$ ile modernistyczną kondycję społeczną charakteryzowała troska o racjonalność, uniwersalizm, planowość, jedność i jednoznaczność, to cechami znamionującymi kondycję postmodernistyczną są: pluralizm, różnorodność, fragmentaryczność, przypadkowość i ambiwalencja. Podstawowym rysem postmodernistycznego stylu myślenia i życia jest negatywna ocena kompetencji rozumu. Zanegowanie zdolności rozumu ludzkiego jest podstawą uprawomocnienia wielości prawd i zasad moralnych, odrzucenia obiektywnego sensu rzeczywistości, teleologicznej wizji świata, zanegowania zasad jedności i uniwersalności oraz deprecjonowania kulturowego i społecznego wymiaru ludzkiej egzystencji. W dziedzinie etycznej postmodernizm proponuje odrzucenie ogólnych norm moralnych i w próbie odrzucenia etyki widzi możliwość ożywienia moralności. Na przekór postmodernistycznym hasłom wzmaga się z wielu stron wołanie o etykę, a pytania etyczne są dziś stawiane bardziej natarczywie niż kiedykolwiek przedtem. ${ }^{17}$

Zmieniająca się rzeczywistość świata i człowieka jest zawsze szczególnym wyzwaniem dla Kościołów chrześcijańskich. Szczególnie dziś Kościoły uświadamiają sobie dobrze, że - jak to trafnie ujęła soborowa konstytucja Gaudium et spes - „należy poznać i rozumieć świat, w którym żyjemy, jego dramatyczne oczekiwania, dążenia i nadzieje". ${ }^{18}$ Gdy na II Soborze Watykańskim Kościół zaczął przyglądać się uważniej własnemu obliczu, gdy do głosu doszły nurty reformatorskie, stało się oczywiste, że pierwszym zadaniem Kościoła rozpoczętym przez ten Sobór powinna być wewnętrzna

15 Zob. Z. S a r eło, Postmodernistyczny styl myślenia i życia, w: t e n ż e (red.), Postmodernizm. Wyzwanie dla chrześcijaństwa, Warszawa 1995, s. 9-27; por. S. Mor a w s ki, Niewdzięczne rysowanie mapy... O postmodernizmie i kryzysie kultury, Toruń 1999, s. 85-120.

16 Por. B. Ś 1 i w e r s k i, Współczesne teorie i nurty wychowania, Kraków 1998, s. 357-386.

17 Por. Z. S a r eło, Postmodernistyczny styl myślenia i życia, s. 10, 26.

18 GS, nr 4. 
jego odnowa, aggiornamento pojmowane jako accomodatarenovatio, czyli taka przemiana oblicza Kościoła, która z jednej strony będzie powrotem do źródeł, do Ewangelii i obrazu Kościoła pierwszych wieków, a z drugiej strony dostosowaniem życia Kościoła do zmieniających się uwarunkowań nowych czasów. Nie chodziło przy tym o upodobnienie się Kościoła do świata, ale otwarcie na świat i problemy, którymi on żyje. To zamierzenie podjęte na Soborze oznaczało bardzo daleko idące zmiany modelu Kościoła i sposobu ujmowania jego wewnętrznej istoty. Było to konieczne, ponieważ do zmiany stosunku Kościoła do świata i sposobu obecności Kościoła w świecie, a zwłaszcza stylu jego duszpasterskiej misji, potrzebna była nowa świadomość wewnątrz samego Kościoła. Nie można odnowić relacji Kościoła ze światem i współczesnym człowiekiem bez pogłębienia rozumienia samej jego istoty, życia wewnątrz Kościoła. Bez tej wewnętrznej odnowy zmiana obecności Kościoła w świecie byłaby jedynie zmianą taktyki działania, pewnym retuszem czysto zewnętrznej powłoki jego życia.

Uogólniając, można powiedzieć, że Sobór jest tu pewną cezurą, objawił mianowicie wolę przezwyciężenia izolacji Kościoła od świata, otwarcie na świat, człowieka i jego problemy. Świadectwem próby przezwyciężenia tej izolacji była opublikowana w 1965 r. Konstytucja duszpasterska o Kościele w świecie współczesnym Gaudium et spes. Kościół, który w tym dokumencie okazał zrozumienie sytuacji współczesnego człowieka uwikłanego w burzliwy rozwój świata, dość długo będzie się uczył „chodzenia w świecie”. ${ }^{19}$ Nastawiony wcześniej bardziej na „ratowanie dusz”, chce zwrócić się do człowieka, który stąpa po ziemi, chce spełnić swoje posłannictwo nie tylko w szafarstwie sakramentów, ale w świetle Ewangelii interpretować najtrudniejsze problemy współczesności.

Homogeniczne społeczeństwo epoki preindustrialnej kształtowało tradycyjnych chrześcijan. Proces religijnej socjalizacji przebiegał wtedy bez większych zakłóceń, ponieważ przekazywane w rodzinie

19 Por. W. B u h $1 \mathrm{~m}$ a n n, Gdzie żyją wiarq. Kościół u progu XXI wieku, Warszawa 1985, s. 57. 
religijne normy i wartości znajdowały potwierdzenie w innych środowiskach, takich jak: szkoła, miejsce pracy, rozrywki, nie mówiąc o wpływie katechumenatu wspólnoty parafialnej czy ogólnej atmosfery życia społecznego sprzyjającej asymilacji wartości religijnych i zwyczajów kościelnych. Jednostka mogła stosunkowo łatwo przyswajać wartości i wzorce zachowania, które były częścią składową oficjalnej kultury, a religia była gwarantem ładu moralnego w życiu codziennym. ${ }^{20}$ Zmiany oblicza współczesnego społeczeństwa, o których wyżej wspominałem, przynoszą także daleko idące przemiany mające wpływ na charakter życia religijnego i sytuację Kościoła. Przestaje on być monopolistą na rynku konkurujących ze sobą systemów oferujących określony styl życia, choć jego rola nie przestaje być ważna i znacząca. Traci on wiele ze swych funkcji, które przejmowane są przez świeckie grupy, a sam koncentruje się na funkcjach ściśle religijnych. ${ }^{21}$

Współczesne uwarunkowania wychowania religijnego

II Sobór Watykański w Deklaracji o wychowaniu chrześcijańskim określa wychowanie jako dążenie do „kształtowania osoby ludzkiej w kierunku jej celu ostatecznego, a równocześnie dla dobra społeczności, których człowiek jest członkiem, i w których obowiązkach, gdy dorośnie, będzie brał udział. Należy więc zgodnie z postępem nauk psychologicznych, pedagogicznych i dydaktycznych dopomagać dzieciom i młodzieży do harmonijnego rozwijania właściwości fizycznych, moralnych i intelektualnych". ${ }^{22} \mathrm{~W}$ tak definiowanym wychowaniu chrześcijańskim mieści się kilka istotnych elementów. Soborowy dokument w pierwszej kolejności podkreśla, że najgłębszą

20 Por. J. M a r i a ń s k i, Moralność w procesie przemian. Szkice socjologiczne, Warszawa 1990, s. 43-44.

${ }^{21}$ Por. R. K a m i ń s k i, Duszpasterstwo Kościołów w społeczeństwie pluralistycznym, s. 29-31.

22 S obó r Wa t y k án s k i II, „Gravissimum educationis”. Deklaracja o wychowaniu chrześcijańskim, w: M. P r z y b ył (tłum.), Sobór Watykański II. Konstytucje, dekrety, deklaracje, $\mathrm{nr} 1$. 
istotą wychowania chrześcijańskiego jest doskonalenie człowieka jako osoby. Nie chodzi zatem o kształtowanie człowieka w sensie jego rozwoju jako gatunku, ale o doskonalenie każdego indywidualnego człowieka. ${ }^{23}$ Oznacza to, że osoba ludzka jest ostatecznym celem wychowania. ${ }^{24}$

Drugi istotny element to płaszczyzny wychowania. Jeśli ostatecznym celem wychowania jest człowiek jako osoba, tzn. jego doskonalenie, to musi ono przebiegać we wszystkich płaszczyznach i dziedzinach: fizycznej, moralnej, intelektualnej, duchowej itp. Pominięcie którejś $\mathrm{z}$ tych płaszczyzn w wychowaniu byłoby zaprzeczeniem samej istoty chrześcijańskiego wychowania, a więc zaprzeczeniem kształtowania człowieka jako osoby. Osoba bowiem, która w najgłębszej swej istocie bytowej jest niepodzielna, domaga się całościowego i integralnego rozwoju..$^{25}$

Trzeci wreszcie istotny element soborowej definicji wychowania chrześcijańskiego ukazuje tzw. kierunek, ku któremu zmierzać winno wychowanie. Inaczej mówiąc, owo kształtowanie człowieka jako osoby, co jest istotnym elementem wychowania, konieczne jest po to, by człowiek mógł zrealizować swoje ludzkie cele, w tym przede wszystkim cel ostateczny. Ponieważ jednak realizacja celu ostatecznego dokonuje się przez udział człowieka w konkretnej rzeczywistości społecznej, w całym procesie chrześcijańskiego wychowania, chodzi o kształtowanie osoby ludzkiej w kierunku jej celu ostatecznego, ale również dla dobra społeczności, której człowiek jest członkiem, w której żyje i działa.

Biorąc pod uwagę takie rozumienie chrześcijańskiego wychowania, należy jednoznacznie stwierdzić, że w całym procesie tego wychowania, którego ostatecznym celem jest człowiek jako osoba,

23 Por. J. M aj k a, Wychowanie chrześcijańskie-wychowaniem personalistycznym, w: F. A d a m s k i (red.), Wychowanie w rodzinie chrześcijańskiej, Kraków 1982, s. 51.

${ }^{24}$ Zob. J.M. B e rg o g li o/ P a p i ė Fra n c is ze k, Wymagania i pasja. O wychowaniu chrześcijańskim, Kraków 2013.

25 Por. H. S k o r o w s k i, Wychowanie do postaw etycznych w spoleczeństwie demokratycznym, Seminare 10/1994, s. 119-135. 
nie może zabraknąć płaszczyzny etycznej ukierunkowanej na rzeczywistość społeczną. Chodzi o potrzebę kształtowania określonych postaw etycznych umożliwiających człowiekowi właściwe funkcjonowanie w rzeczywistości społecznej, w której realizuje on swój cel ostateczny. Wychowanie bowiem do postaw etycznych, stanowiące integralny element chrześcijańskiego wychowania, nabiera w dobie dzisiejszej szczególnego znaczenia. ${ }^{26}$

Człowiek od dzieciństwa rozwija się w klimacie konkursów, quizów, losowań. Uczy się, że dobro, które być może go spotka, będzie rezultatem przypadku, a nie dziełem Opatrzności. W sumie otrzymuje obraz świata, zdarzeń, wreszcie siebie, wyizolowany z transcendentnych odniesień. Spotkanie się współczesnej cywilizacji technicznej, gospodarki rynkowej oraz zyskującej na znaczeniu mentalności konsumpcyjnej generuje swoisty model życia propagowany w skrajnej postaci przez wiele telewizyjnych reklam. Te ostatnie próbują przekonać człowieka, że będzie szczęśliwy, jeśli zaspokoi potrzeby materialne: posiadania, jedzenia, wygody, rozrywki. ${ }^{27}$ Mamy oto człowieka postawionego jakby na targowisku i mającego wśród bogactwa towarów dokonywać wyborów. W konsekwencji zmiany sposobu funkcjonowania człowieka w systemie ekonomicznym zmienia się sposób jego funkcjonowania w innych systemach: kulturowym, religijnym, moralnym, obyczajowym. ${ }^{28}$

Demokracja a wolność i godność człowieka

Współczesna pochwała demokracji jest zrozumiała i cenna, gdy chodzi o postulat demokratycznych procedur wyłaniania kandydatów do organów przedstawicielskich czy uzgadniania metod zespołowego działania. Gorzej, gdy w sposób demokratyczny usiłuje się orzekać o prawdzie (w tym o prawdziwości tez wiary) czy o dobru (w tym

26 Por. P. To m a s i k, Nauczanie religii w publicznym liceum ogólnokształcacym wobec założén programowych polskiej szkoty, s. 313n.

27 Por. tamże, s. 22.

28 Por. tamize. 
o zasadności postulatów moralnych). Pokusa głosowania nad słusznością i obowiązywalnością norm moralnych to jedna z ważniejszych pokus ludzi zafascynowanych demokracją. W nowoczesnym społeczeństwie pluralizm zmienia się w neutralność wartości. Uważa się przy tym, że w imię fałszywie rozumianej demokracji można dowolnie rezygnować ze stosowania norm etycznych w życiu publicznym. ${ }^{29}$

Pojęcie demokracji wiąże się nierozdzielnie z ideą wolności, która jest wielkim osiągnięciem czasów nowożytnych. Ta idea, jak się wydaje, w sposób jednoznaczny zdominowała myślenie współczesnego człowieka i całego świata, przybierając postać tzw. nowego humanizmu. Jest faktem niepodważalnym, że demokracja musi stwarzać horyzonty wolności dla osoby ludzkiej. Człowiek bowiem jest istotą bytowo wolną, tzn. wolną w najgłębszej swej istocie, i dlatego musi mieć zapewnione płaszczyzny realizacji swojej bytowej wolności. ${ }^{30}$ „Człowiek musi mieć jakieś pole wolności i swobody. Człowieczeństwo to także indywidualna, spontaniczna twórczość człowieka. Poprzez wolność przejawia się bogactwo osoby ludzkiej, którego nie można ograniczać żadną funkcją. Człowiek jest artystą swego życia i rzeźbi je według własnych wyobrażeń o swym szczęściu i honorze. Wolność jest zawsze związana z jakimś stopniem nieprzewidywalności. Wolność jest niezbędna. (...) Bez wolności żaden czyn, żadne pragnienie, żadne spełnienie funkcji nie będzie własnym czynem człowieka. Człowiek winien być sobą w swych czynach. Gdzie brak wolności, tam człowiek nie jest sobą - nawet gdy robi, co od niego wymagają". ${ }^{31}$

W świetle katolickiej nauki społecznej, rzeczywistą, fundamentalną ideą demokracji jest godność człowieka jako jednostki i wspólnoty osób. Każdy ową godność odczuwa i definiuje na swój sposób:

29 Por. tamże, s. 237; J a n P a w e 1 II, Przemówienie na spotkaniu z prezydentem Republiki Federalnej Niemiec i innymi władzami, nr 4.

30 Por. te n że, Chcesz służyć sprawie pokoju - szanuj wolność. Orędzie na międzynarodowy Dzień Pokoju 1981, w: t e n ż e, Nauczanie społeczne, t. IV, Warszawa 1984, nr 11.

31 J. T i s c h n e r, Etyka solidarności, Kraków 1981, s. 49. 
„człowieczeństwo”, „natura ludzka”, „godność”, ale to, co podstawowe w tym pojęciu, jest wspólne. Oczywistość godności ludzkiej nie podlega dziś dyskusji; „,W poczuciu godności odnajdujemy się dziś wszyscy: robotnicy, chłopi, ludzie kultury i nauki. Idea godności jest tłem wszystkich nadziei konkretnych. Nawet w wołaniu o chleb jest wołanie o uznanie godności. Dlatego jest to dziś podstawa naszej demokracji". ${ }^{2}$ To właśnie godność człowieka jako jednostki i wspólnoty osób mówi nam o potrzebie takiego systemu (rzeczywistości) społecznego, który jest nowym i jedynie właściwym typem stosunków międzyludzkich, stosunków opartych na poszanowaniu godności wszystkich ludzi, a tym samym stosunków wyznaczających horyzonty prawdziwej wolności każdego, ale i odpowiedzialności. I to jest istotne dopowiedzenie - wolności, ale także odpowiedzialności. Zdążanie współczesnego świata ku demokracji, także w polskiej rzeczywistości, musi być zdążaniem ku społeczności ludzi wolnych, ale także odpowiedzialnych za poszanowanie godności każdego człowieka. Prawdziwie wolnych, bo odpowiedzialnych. To zaś jest możliwe tylko wtedy, gdy to, co buduje człowiek w sferze życia społecznego, opierać się będzie na idei godności człowieka.

Człowiek-osoba przerasta sobą całą otaczającą go rzeczywistość. Jako osoba charakteryzuje się on bowiem posiadaniem siebie, dysponowaniem sobą, nieprzekazywalną odpowiedzialnością za siebie, co w praktyce oznacza, że nie może on być zawłaszczony przez żadną instytucję, lecz należy do siebie; nie może być przez żadną inną osobę wykorzystany, ponieważ sam dla siebie jest celem zasadniczym; nie może być przez nikogo reprezentowany, lecz sam odpowiada za siebie. Biorąc to pod uwagę, należy w odniesieniu do człowieka mówić o jego niepowtarzalnej wartości. Z pojęciem osoby w ścisłej relacji stoi zatem kolejna prawda, którą jest przekonanie o najwyższej i niepowtarzalnej wartości osoby określane terminem ,godność osobowa”. Tylko w odniesieniu do człowieka jako osoby możemy mówić o godności. Pojęcie godności zawiera w sobie treść aksjologiczną. Wyraża bowiem kwalifikacje i ocenę, tzn. jest

32 Tamże, s. 50. 
przypisywaniem wyjątkowej wartości człowiekowi ze względu na doniosłość stanowiącego go tworzywa ontycznego. ${ }^{33}$

Postawa miłości, jako fundamentalna postawa etyczna w ramach życia społecznego, to w pierwszej kolejności relacja do drugiego człowieka jako jednostki, w której to relacji odczytuje się drugiego człowieka jako wartość, otwiera się na niego, afirmuje przez afirmację jego dóbr i wartości, a konsekwentnie dalej aktywnie współuczestniczy w jego życiu, upewniając go w jego godności. Postawa miłości, w ujęciu chrześcijańskim, dotyczy jednak nie tylko odniesienia do drugiego człowieka jako jednostki, ale także odniesienia do człowieka jako wspólnoty osób. Jest to tzw. miłość społeczna. Kiedy mówimy o miłości społecznej jako postawie, to mamy na myśli nie relację do konkretnej jednostki, ale zastosowanie tej pierwszej do życia społecznego w sensie relacji do wspólnoty. Postawa miłości w tym odniesieniu jest treścią relacji osoby do rodziny, społeczności sąsiedzkiej i zawodowej, grupy terytorialnej, społeczności narodowej i państwowej, wspólnoty kościelnej. ${ }^{34}$ Oczywiście odniesienia człowieka do poszczególnych wspólnot i grup nie można odizolować od jego odniesienia do konkretnego człowieka. Nie ma bowiem żadnej wspólnoty obok czy poza człowiekiem. W każdej z nich podstawowym podmiotem jest osoba ludzka. Postawa miłości jako odniesienie człowieka do grupy jest zatem de facto odniesieniem do osób tę grupę stanowiących, chociaż nie w bezpośredniej relacji, ale w relacji wspólnotowej.

Przeszkody utrudniające wychowanie moralne

Wydaje się, że niebezpieczeństwa w dziedzinie wychowania grożą zwłaszcza społeczeństwom o najwyższej cywilizacji technicznej. Społeczeństwa te stoją wobec swoistego kryzysu człowieka, polegającego na rosnącym braku zaufania do własnego człowieczeństwa, do samego sensu bycia człowiekiem, do płynącej z tego

33 Por. tamże, s. 42, 73-75.

34 Por. tamże, s. 29. 
afirmacji i twórczej radości. Cywilizacja współczesna stara się narzucić człowiekowi wiele pozornych imperatywów, które jej rzecznicy uzasadniają prawem rozwoju i postępu. Na przykład na miejsce poszanowania życia - imperatyw pozbywania się i niszczenia życia; na miejsce miłości jako odpowiedzialnej wspólnoty osób - sumę użycia seksualnego zwolnionego od wszelkiej odpowiedzialności; na miejsce prymatu prawdy w działaniu - prymat sensacji, koniunktury i doraźnego sukcesu. ${ }^{35}$

Wiadomymi znakami relatywizacji świata wartości są: sytuacjonizm zakładający zmienną (dostosowana do bieżącej sytuacji) hierarchię wartości; liberalizm promujący wolność dla samej wolności i nie odwołujący się do świata wartości obiektywnych; pluralizm oferujący możliwość wyboru rozlicznych dóbr, lecz dający małe szanse na zdobycie umiejętności dokonywania wyborów. ${ }^{36}$

W społeczeństwie pluralistycznym, absolutyzującym rozum, pracę i sukces, w którym ludzie są przyzwyczajeni do panowania nad materią oraz przekształcania jej według swej woli, powstaje niebezpieczeństwo manipulowania sumieniem i jego wymogami. Analizując sytuację dzisiejszego człowieka, można stwierdzić, że przyczyną tego stanu rzeczy jest zanik świadomości Boga i kryzys sumienia. Kiedy bowiem zaciemnia się rzeczywistość Boga, ulega wypaczeniu sumienie człowieka; kiedy zanegowany zostaje grzech, następuje także negacja Boga. ${ }^{37}$

Współczesny człowiek coraz bardziej zdaje się być zagrożony przez to, co jest wytworem, wynikiem pracy jego rąk, a zarazem

35 Por. Ja n P a w e $\nmid$ II, W imię przyszłości kultury. Przemówienie w UNESCO (2 VI 1980), OsRomPol 6/1980, s. 1, 4-6.

36 Por. A. P o t o c k i, Między autorytetem a dialogiem. O przemianach autorytetów, w: K. M r o c z e k (red.), Wychowawca na czas próby. Jakiego człowieka chcemy wychować?, Marki-Struga 1997, s. 37.

37 J a n Paw eł II, Przemówienie na spotkaniu z Konferencja Episkopatu Austrii w Salzburgu (24 VI 1988), OsRomPol 7/1988, s. 25; t e n ż e, Przemówienie na spotkaniu z młodzieża w Denver (14 VIII 1993), OsRomPol 11/1993, s. 29. 
pracy jego umysłu, dążeń jego woli. ${ }^{38}$ Zagrożenia te to, przede wszystkim, zagrożenie przez fałsz (kłamstwo), a więc zagrożenie dla prawdy oraz zagrożenie przez złe wybory moralne, co łączy się z fałszywym pojmowaniem ludzkiej wolności ${ }^{39} \mathrm{Na}$ straży wartości, jaką jest prawda, stoi ósme przykazanie Dekalogu. Przykazanie to w szczególny sposób wiąże się z prawdą, która obowiązuje każdego człowieka w obcowaniu z innymi ludźmi i w całym życiu społecznym: „Nie mów fałszywego świadectwa” (por. Wj 20,16). Tym przykazaniem Bóg Przymierza daje poznać, że człowiek jest stworzony na Jego obraz i podobieństwo. Dlatego całe ludzkie postępowanie poddane jest wymogom prawdy. Prawda jest dobrem, a kłamstwo, fałsz, zakłamanie jest złem. Doświadczamy tego w różnych wymiarach i w różnych układach. Nie ulegającym wątpliwości zaprzeczeniem prawdy, a tym samym grzechem przeciwko prawdzie jest kłamstwo. Kłamstwo, które jest naruszeniem prawdomówności, jest wszelką mową wbrew przekonaniu mówiącego, a tym samym wykroczeniem przeciw wartości moralnej, jaką jest prawdziwość ludzka.

W procesie przekazu bardzo ważną rolę odgrywają media. W swoim rozległym funkcjonowaniu są albo nośnikiem różnorakiego dobra, kierowanego do jednostki i społeczeństwa, albo też stają się czynnikiem upowszechniającym zło. Jan Paweł II w Redemptor hominis opisuje sytuację, gdy człowiek staje się przedmiotem wielorakiej - czasem bezpośrednio nieuchwytnej - manipulacji przez nacisk środków przekazu społecznego. ${ }^{40}$ Manipulowanie prawdą w środkach masowego przekazu jest szczególnie groźne wychowawczo, ponieważ swym wpływem obejmują one ogromną liczbę ludzi, niezależnie od wieku, wykształcenia, rasy, religii czy światopoglądu. ${ }^{41}$ Jest to niezwykle groźne dla rozwoju osobowego człowieka, bo

38 Te n że, „Redemptor hominis”. Encyklika u początku papieskiej posługi (1979), w: Encykliki Ojca Świętego Jana Pawła II, Kraków 2000, nr 16 (dalej: RH).

39 Por. I. D e c, Zagrożenia życia indywidualnego, w: J. N a g ó r n y, A. D e r d zi u k (red.), Teologia moralna wobec współczesnych zagrożén, Lublin 1999, s. 24.

40 Por. RH, nr 16.

${ }^{41}$ Por. J. G a j d a, Wartości w życiu człowieka, Lublin 1997, s. 40. 
może spowodować zniekształcenia jego hierarchii wartości. Zatrucie informacyjne w mediach polega na tym, że sprawy ważne pokazuje się jako mało ważne, a sprawom nieważnym nadaje się duże znaczenie. W ten sposób dekomponuje się lub uniemożliwia ukształtowanie optymalnej hierarchii wartości. ${ }^{42}$

Kolejną ideologią, która zamazuje prawdę o człowieku jest współczesny liberalizm, sięgający swymi korzeniami do haseł rewolucji francuskiej. W kierunku tym z kolei człowiek został pomylony $\mathrm{z}$ aniołem, a niekiedy z Bogiem. Osobę ludzką uznano za istotę wolną od wszelkich zobowiązań, od wszelkich kodeksów etycznych i religijnych. Przyznano jej władzę do określania dobra i zła, do kreowania według nich subiektywnych kryteriów, prawdy i dobra. Przypisano człowiekowi te cechy, które tradycja chrześcijańska odnosiła do samego Boga. Odżyła więc rajska pokusa: „Będziecie jako Bogowie". ${ }^{43}$

Swoistym przedłużeniem liberalizmu etycznego jest dzisiejszy postmodernizm, który neguje wszelkie wartości poznawcze i moralne, podważa moc poznawczą ludzkiego rozumu, neguje obiektywną prawdę i obiektywne dobro, neguje sens i cel życia ludzkiego, a co za tym idzie, wypacza obiektywny wizerunek człowieka. ${ }^{44}$ Konsekwencje aprobaty postaw głoszonych przez współczesny liberalizm i postmodernizm napawają dziś przerażeniem. Aborcja, eutanazja, samobójstwa, wandalizm, alkoholizm, narkomania, zanik poczucia odpowiedzialności za swoje czyny, utrata orientacji w sferze dobra i zła moralnego, odrzucanie form życia religijnego to główne symptomy skrajnego liberalizmu i postmodernizmu. ${ }^{45}$

Powyższe systemy myślowe wyznaczają określone działania moralne i stanowią wyraźne zagrożenie dla indywidualnego człowieka.

42 Por. W. P awłow s k i, Manipulacja w środkach masowego przekazu, w: (zbior.), Wobec socjotechniki, Kielce 1998, s. 46; A. L e p a, Świat manipulacji, Częstochowa 1997, s. 71-75.

43 Por. I. D e c, Zagrożenia życia indywidualnego, s. 25.

44 Por. H. S e w e r y n i a k, Świadectwo i sens, Płock 2001, s. 67-68.

45 Por. Z. S a r eł o, Postmodernistyczne inspiracje, w: J. N a gó r n y, A. D e r d z i u k (red.), Teologia moralna wobec współczesnych zagrożeń, s. 66. 
Są wyjątkowo niebezpieczne, gdyż fałszują prawdę o człowieku, wypaczają prawdę o wolności człowieka, o jego godności, a także podstawowych prawach i obowiązkach. Dzisiaj widać wyraźne następstwa tamtego czasu. Najważniejsze z nich to przyzwyczajenie się społeczeństwa do aktów zakłamania w życiu społecznym, wykluczające u bardzo wielu ludzi jakikolwiek sprzeciw czy protest. W świadomości rzeszy ludzi istnieje ponadto przekonanie, że jakakolwiek ich interwencja w sprawie zniekształcanej prawdy z gruntu będzie bezskuteczna, a nawet wysoce ryzykowna.

W świecie współczesnym dominuje wiele błędnych koncepcji wolności. Coraz częściej wolność jest uznawana za całkowitą niezależność od czegokolwiek. Tak rozumiana wolność jest raczej dobrowolnością i nieporozumieniem, aniżeli wiernością prawdzie i dobru. Wolność jako niezależność jest raczej marzeniem oderwanym od realności. Dzisiaj wolność traktuje się również jak wolność do czegoś i wolność od czegoś. Człowiek jest przekonany o tym, że może czynić co chce i wybierać to, na co ma ochotę. Błędne koncepcje wolności $\mathrm{i}$ ich błędne skutki ujawniają $\mathrm{u}$ ich postaw błędną koncepcję człowieka. Są oparte na pomijaniu lub wykluczaniu w człowieku roli jego intelektu. Podejmując jakiekolwiek kwestie o świecie współczesnym, nie możemy nie odnieść się do wolności, gdyż ta jest jedyną w swoim rodzaju wartością etyczną, od której rozumienia i realizacji zależy realizowanie się człowieka, a wraz z nim wartości osobowe.

Podważając wolność i wszelkie wartości moralne, podważa się godność osoby ludzkiej i nienaruszalność jej życia. W rzeczywistości nikt nie może uznać nieograniczonego prawa do decydowania o własnym życiu i śmierci. Różnorodne sytuacje życiowe nieustannie skłaniają człowieka do podejmowania decyzji. Współczesność doprowadziła jednak do absolutyzacji wolności człowieka. Doszło do powstania teorii całkowitej suwerenności rozumu w dziedzinie norm moralnych, służących właściwemu uporządkowaniu życia w tym świecie. Normy te miałyby stanowić obszar moralności wyłącznie ludzkiej, to znaczy wyrażać prawo, które człowiek autonomicznie nadaje samemu sobie i którego wyłącznym źródłem jest ludzki rozum. W takim rozumieniu człowiek sam staje się twórcą obowiązujących 
norm, posiadaczem obiektywnej wiedzy moralnej, pomijając Boga i Jego prawo. ${ }^{46}$

\section{Czynniki dezorganizujące wychowanie moralne}

Pluralizm stanowi w gruncie rzeczy konsekwencję doskwierającej ułomności człowieka, z powodu której tak trudno prawdę poznać. Wielość poglądów stanowi więc raczej zadanie, a nawet trudność, którą trzeba próbować przezwyciężyć, nie zaś cel, ku któremu należy zmierzać. Kto zadowala się samym pluralizmem, a nie usiłuje go przezwyciężyć, ten daje dowód, że nie o prawdę mu w gruncie rzeczy chodzi; że tzw. dialog jest dlań tylko pretekstem pomocnym do osiągania innych celów, nie zawsze godnych moralnej aprobaty.

\section{Trudny dialog w poszukiwaniu prawdy}

Nie można, zwłaszcza w imię wzajemnego szacunku, bagatelizować tego, czy i w jakim stopniu środowisko lub pismo pretendujące do miana katolickiego jest wierne orzeczeniom Urzędu Nauczycielskiego Kościoła. Chodzi natomiast o to, by wygłaszane tezy i zarzuty były porządnie uzasadnione i by dyskutować ze sobą na poziomie argumentacji, a nie domysłów, pomówień i epitetów - a dotyczy to nie tylko wypowiedzi w środkach masowego przekazu, lecz także praktyki duszpasterskiej. Chodzi o prawdziwy głód prawdy i związaną z nim elementarną pokorę - chodzi o to, by uważnie słuchać tego, co mówią inni, i być gotowym zmienić pogląd, gdy mnie ktoś przekona, że byłem w błędzie. Nawet w głosach niechętnych Kościołowi może znaleźć się wiele prawdy - i więcej dobra przyniesie przyznanie racji krytykom tam, gdzie ją mają, niż usilna obrona siebie w złudnym przeświadczeniu, że broni się Jezusa Chrystusa i Kościoła. Porządna

46 Por. J a n P a w eł II, „Veritatis splendor”. Encyklika o niektórych podstawowych problemach nauczania moralnego Kościoła (1993), w: Encykliki Ojca Świętego Jana Pawła II, nr 36 (dalej: VS); S. R o s i k, Autonomia sfery moralnej i jej uwarunkowania, STV 31(1993) nr 1, s. 44-45. 
polemika nie jest walką bokserską - to raczej wspólna wspinaczka na szczyt, którego żaden człowiek, bez pomocy innych, osiągnąć nie może. Dlatego właśnie pluralizm jest tak cenny: wyraża się w nim ta „uzasadniona różnica” zdań i postaw, dzięki której „tym owocniejsza [jest] wymiana poglądów między wszystkimi, którzy tworzą jeden Lud Boży, zarówno pasterze, jak i ogół wiernych". ${ }^{47}$

Po długim okresie, w którym ortodoksyjna była tylko jedna filozofia i jeden naukowy światopogląd, łatwo zachłysnąć się wolnością rozumianą jako niczym nieskrępowana możliwość wyboru dowolnej opcji z bogatej gamy możliwości. Do takiego właśnie modelu wolności odwołują się ci, którzy „ofertę katolickiej wiary” uzupełniają informacjami o innych wyznaniach chrześcijańskich lub innych religiach, informacjami utrzymanymi często w bardzo życzliwym tonie, który niekoniecznie towarzyszy relacjom z życia katolickiego Kościoła ${ }^{48}$ Rzecz nie w tym, by informacji takich nie było lub by podawane były w nieprzychylnym tonie. Niepokój budzi raczej „rynkowa konwencja”, w jakiej są one zwykle utrzymane. Wyraźna sugestia „możesz wybrać tę” odwraca cały sens religii i podważa rozumność człowieka. Przestaje być celem jego wysiłku zobowiązująca go moralnie prawda: poznanie Boga takiego, jaki jest, i służenie Mu wedle Jego zamysłu. Bóg, religia, moralne konsekwencje wiary stają się przedmiotem „opcji” człowieka, upodobania, które - jako „wolne” - nie wymaga już żadnego usprawiedliwienia.

Gdy dialog nie ma oparcia w prawdzie, wówczas nieuchronnie otwiera się drogę do relatywizmu. To, co dobre i słuszne dla jednego, nie musi być przecież takie dla drugiego, ani nawet dla tego samego człowieka w innych okolicznościach. O randze danej wartości oraz ważności reguł postępowania decyduje wówczas bowiem nie rozpoznana przez człowieka prawda o dobru, lecz inne, pozaracjonalne jego potrzeby i pragnienia, z natury swej zindywidualizowane, zmienne

47 Szerzej na temat procesów zmierzających do relatywizmu zob. A. S z o s t e k, Prawda i dialog: między relatywizmem a pluralizmem, Ethos 1/1997, s. 51-63.

48 Por. S. D z i e k o ń s k i, Formacja chrześcijańska dziecka w rodzinie w nauczaniu Kościoła, Warszawa 2006, s. 205n. 
i z sobą kolidujące. Ten, kto dąży w innym niż ja kierunku, stanowi wówczas dla mnie zagrożenie. Miejsce wspólnoty w prawdzie zajmuje przewaga silniejszego. O sojuszu lub wzbogaceniu nie ma już mowy. Otwiera się więc drogę do totalitaryzmu, którego widmo zjawia się zawsze tam, gdzie prawda przestaje być podstawowym celem dialogu i kryterium oceny postępowania.

Jak więc $\mathrm{z}$ jednej strony nieodzowna jest zasada dialogu, której ważności nie uchylają przykre doświadczenia, niechęć, a nawet podejrzenie o brak dobrej woli, tak z drugiej motorem tej zasady może być ,jedynie umiłowanie prawdy”, której trzeba dociekać z całym szacunkiem dla myślących inaczej, z uważną i pokorną otwartością na ich argumenty - ale jednocześnie z nieustępliwą dociekliwością, przez którą okazuje się większy szacunek partnerowi dyskusji niż przez łatwe ustępstwa i pozorną zgodę.

\section{Zgubne skutki relatywizmu etycznego}

Moralność uważana jest za swoiste wyposażenie człowieka, które uzewnętrznia jego postępowanie. Dlatego też przyrównuje się ją do wewnętrznego kompasu, który ukazuje człowiekowi wewnętrzne nakazy wyboru drogi postępowania w określonych sytuacjach życiowych. ${ }^{49}$ Sam termin moralność oznacza obyczaje lub zwyczaje ludowe określające reguły postępowania człowieka. Pośród wielu definicji moralności czytelną i cenną dla potrzeb niniejszych rozważań pomocą wydaje się definicja J. Piepera, który pod pojęciem moralności rozumie ogół norm oraz odpowiednich nawyków społecznie utrwalonych, pośrednio osobistych, bo przyswojonych przez oddziaływanie norm oraz obyczajów związanych ze współżyciem ludzi ze sobą. ${ }^{50}$

Porządek moralny, właśnie dlatego, że ujawnia i przedstawia zamysł Boży, nie może być czymś, co utrudnia życie człowiekowi i nie odpowiada osobie. Wiara chrześcijańska, będąc rzeczywistością

49 Por. S. S ła w iń s k i, Rozważania o wychowaniu, Warszawa 1983, s. 5-6.

50 Por. A. Z u be rbie r (red.), Stownik teologiczny, Katowice 1998, s. 314; J. P i e p e r, Oceny $i$ wartości, Katowice 1973, s. 140. 
głęboko antropologiczną, odpowiada najgłębszym potrzebom człowieka stworzonego przez Boga, służy jego pełnemu człowieczeństwu z tą samą subtelną i wiążącą miłością, z jaką Bóg pobudza, podtrzymuje i prowadzi do właściwego mu szczęścia każde stworzenie. Nie można bowiem oddzielać od siebie dwóch wymiarów, tzn. wymagań moralności, jakie Bóg stawia człowiekowi, oraz wymagań zbawczej miłości, czyli łaski. ${ }^{51}$ Chrześcijaństwa nie można sprowadzać wyłącznie do moralizmu. Doświadczenie moralne polega nie tyle na pozostaniu w obrębie sztywnych granic normatywnych, ile raczej na ustawicznym stawaniu się samym sobą przez realizację darów natury i łaski. ${ }^{52}$ Moralność nie stawia sobie za cel oswojenie jednostki ludzkiej, aby włączyć ją w ponury system zakazów i nakazów. ${ }^{53}$ Dlatego człowiek, który przeczuwa, że wolność i miłość to coś nieskończenie większego aniżeli zwykłe posłuszeństwo przepisom, i że jego tożsamość wiąże się właśnie z taką miłością i wolnością, wtłoczony w system praw, ratuje swoją godność, stosując bunt. ${ }^{54}$

Człowiek często zapomina o tym, że ilekroć pragnie się wyzwolić od prawa moralnego i uniezależnić od Boga, bynajmniej nie zyskuje wolności, lecz ją niszczy, staje się ofiarą własnych dzieł. ${ }^{55}$ Dające się słyszeć w takich wizjach wołanie o wolność staje się w stechnicyzowanym świecie wołaniem o pomoc. ${ }^{56}$ Wszak zasada, że wszystko mi wolno, prowadzi w istocie do niszczenia wolności i godności drugiego człowieka, a ostatecznie do anarchii i bezprawia. ${ }^{57}$ Gdy ludzie nie oczekują już niczego innego, a tylko tego, co oferuje im ten świat,

51 Por. J a n P aw eł II, Przekroczyć próg nadziei, Lublin 1994, s. 46, 163; zob. B e n e d y k t XVI, „Deus caritas est”. Encyklika o miłości chrześcijańskiej, Watykan 2005.

52 Por. S. W i e 1 g u s, Kościół katolicki dziś. Zagrożenia, ich przyczyny oraz drogi wyjścia, Nasz Dziennik, 16-17 XI 2002, s. 16.

53 Por. A. Fro s s a r d, Bronię papieża, Warszawa 1995, s. 55.

54 Por. S. G r y g i e 1, Kimże jest człowiek? Kielce 1995, s. 234.

55 Por. G. P u c h a l s k i, Wzajemne przenikanie się ewangelizacji i katechezy, Studia Elbląskie 2000, t. 1, s. 305.

56 Por. J. R a t z i n g e r, Duch liturgii, Poznań 2002, s. 151.

57 Por. L. B a l t e r, Naród, wolność, demokracja, ComP 9/1994, s. 14. 
niszczą siebie i wszelkie życie wspólnotowe. ${ }^{58}$ Pozbawiona treści wolność indywidualna, która jawi się jako cel najwyższy, wyklucza siebie, ponieważ indywidualna wolność istnieć może tylko w hierarchii wartości. Potrzebuje miary, gdyż w przeciwnym przypadku staje się wobec innych przemocą. Wolność wyraża się najbardziej doskonale w tym, co zdaje się jej przeczyć, w tym: nie mogę i muszę. Dlatego w dziedzinie moralności człowiek w żadnym wypadku nie może postępować samowolnie. W każdej dziedzinie zakaz jest potrzebny do zagwarantowania wartości. Przyjęcie zakazu tak długo sprawia trudności, jak długo nie rozumiemy jego celu. ${ }^{59}$

Sumienie chrześcijanina kształtowane jest przede wszystkim na podstawie Ewangelii. Formująca sumienie chrześcijańskie, mocą miłości Boga i bliźniego, moralność Ewangelii, jest moralnością otwartą, gdyż właśnie w Ewangelii została przez Chrystusa przekreślona zasada wierności duchowi na niekorzyść wierności literze. ${ }^{60}$ Zakaz, choćby postawiony przez Boga, nie będzie respektowany, póki człowiek nie pojmie, że, przekraczając ten zakaz, sam traci jakieś dobro. Dobro winno być ukazane jako wartość, o którą warto się troszczyć, dla której opłaci się podjąć trud i wyrzeczenia. Ono jest istotnie wpisane $\mathrm{w}$ dynamizm naszego życia. ${ }^{61}$ Rola sumienia, szerzej: rola osoby ludzkiej, szukającej własnej, osobistej drogi postępowania i kierującej się w wyborze środków tylko względami dobra, jest w kwestii obowiązywalności prawa czymś zasadniczym, od czego nie może być i nie ma żadnego zwolnienia. Nie oznacza to przekreślenia przykazań i nakazów, ale postawienie na pierwszym miejscu czynienia dobra. ${ }^{62}$

Egzystencjalizm w wymiarze areligijnym składa współczesnemu człowiekowi propozycję - może on podejmować się wszystkiego i nie

58 Por. J. R a t z i n g e r, Znaczenie wartości religijnych i etycznych w spoteczeństwie pluralistycznym, ComP 9/1994, s. 183, 197.

59 Por. W. P ó $ł$ t a w s k a, Rola rodziców w wychowaniu seksualnym młodzieży, w: F. A d a m s k i (red.), Wychowanie w rodzinie chrześcijańskiej, s. 334.

${ }^{60}$ Por. S. R o s i k, Wezwania i wybory moralne, Lublin 1992, s. 250.

${ }_{61}$ Por. P. J a r o s z y ń s k i, Dramat życia moralnego, Warszawa 2001, s. 97.

62 Por. M.A. K r ą p i e c, Człowiek i prawo naturalne, Lublin 1986, s. 236. 
ma dla niego zakazanej dziedziny. Dla tego toku myślenia charakterystyczne jest to, że wielkość moralna polega nie na realizacji pewnego ustalonego sposobu istnienia, natury ludzkiej, ale na możliwości nieustannego tworzenia siebie w sposób wolny, przez grę własnej wolności. ${ }^{63} \mathrm{~W}$ ostateczności prowadzi to do definiowania wolności przez nią samą i do uznania jej za instytucję tworzącą siebie i swoje wartości. ${ }^{64}$

Wrażliwość moralna to nie przejaw naiwności czy przesadnej religijności, ale wyjątkowo ważna forma inteligencji człowieka. Oznacza ona bowiem inteligentne odróżnianie zachowania, które nas rozwija i cieszy, od zachowania, przez które krzywdzimy siebie czy innych ludzi i które nas niepokoi. Potrzeba kształtowania dojrzałej wrażliwości moralnej nie wynika z jakichś przestarzałych albo niepotrzebnych tradycji czy założeń pedagogicznych, lecz z faktu, że człowiek potrafi krzywdzić siebie i innych. W tej sytuacji przejawem wyjątkowej inteligencji i mądrości jest precyzyjne odróżnianie zachowania rozsądnego od zachowania błędnego i szkodliwego. Człowiek pozbawiony inteligencji moralnej jest skazany na czynienie tego, co łatwiejsze, ale szkodliwe, zamiast tego, co wartościowe i mądrzejsze, chociaż trudniejsze i nie promowane przez kulturę ponowoczesności. ${ }^{65}$

\section{Postmodernistyczny charakter współczesności}

Liberalizm zarówno ekonomiczny, jak i moralny kontrastuje z katolicką wizją społeczeństwa i etyki personalnej: „W świecie, gdzie (...) pieniądz i bogactwo są miarą wszystkiego, gdzie wolnorynkowość narzuca swoje nieubłagane prawa każdej dziedzinie życia, autentyczna etyka katolicka wielu ludziom wydaje się obcym ciałem, przeżytkiem, rodzajem meteorytu kontrastującym nie tylko z konkretnymi zwyczajami życia, ale także z podstawą sposobu myślenia.

63 Por. P. G ó r a l c z y k, Wychowawcza etyka seksualna, Ząbki 2000, s. 18-19.

${ }^{64}$ Por. VS, nr 46.

65 Por. Por. M. D z i e w i e c k i, Wychowanie w dobie ponowoczesności, Kielce 2005, s. 78. 
Liberalizm w dziedzinie ekonomicznej odpowiada na płaszczyźnie moralnej permisywizmowi". ${ }^{66}$

Wśród wielu dziedzin współczesnego życia, które znalazły się w stanie kryzysu, trzy wydają się szczególnie nim dotknięte: filozofia, etyka i sztuka. U podstaw artykułowania tego kryzysu leży postmodernistyczne spojrzenie na świat, a w szczególności postmodernistyczna wizja człowieka i jego miejsca w świecie. ${ }^{67}$ Postmoderniści, podkreślając kulturowy i historyczny kontekst i wymiar ludzkiego poznania, przypisują mu ewidentne znamię historyczności ${ }^{68}$ Poznanie jest niemożliwe poza kontekstem kulturowym. Proces poznania nie polega bowiem na odkrywaniu prawdy, a raczej na jej tworzeniu, ponieważ fikcją jest zakładana odrębność światów: poznawanego, istniejącego wcześniej, niezależnie od procesu poznania i poznającego. Rzecz bowiem w tym - twierdzą postmoderniści - że „,dopóki pozostajemy na gruncie wiedzy pojęciowej, nie mamy do dyspozycji żadnych środków, by dotrzeć do jakiejś «czystej», «prawdziwej» rzeczywistości, usytuowanej przed lub poza kategoriami naszej wiedzy". 69

\section{Odrzucenie prawdy i aksjologiczna pustka}

Uprawiana dotąd filozofia przeżyła się i jest nieprzydatna w erze postmodernistycznej. Także w przyszłości nie przewiduje się dla niej

${ }^{66}$ Raport o stanie wiary. Z ks. kardynałem Josephem Ratzingerem rozmawia Vittorio Messori, Warszawa 1986, s. 71; zob. A. M c C o y, Etyka chrześcijańska, Poznań 2007.

${ }^{67}$ Zob. W. M a j k ow s k i, Rodzina polska w kontekście nowych uwarunkowań, Kraków 2010, s. 186-192.

${ }^{6}$ Tezę uhistorycznienia życia i poznania głosili już przedstawiciele niemieckiego historyzmu. E. Troeltsch pisał: „Państwo, prawo, moralność, religia, sztuka roztapiają się w rzece stawania się dziejów i są dla nas zrozumiałe tylko jako części składowe przemian historycznych"; cyt. za: C. A n t o n i, From History to Sociology. The Transition in German Historical Thinking, London 1962, s. 75.

${ }^{69}$ A. Zy b e r t o w i c z, Przemoc i poznanie. Wstęp do nie-klasycznej socjologii wiedzy, Toruń 1995, s. 101. 
roli. W żadnym wypadku zaś nie jest sposobem odkrywania prawdy ani wyrazem racjonalności ludzkiego poznania. Prawda niezależna od ludzkiego umysłu nie istnieje. Taka prawda stałaby w sprzeczności z ludzką wolnością. Taka prawda byłaby „«totalizująca», «hegemoniczna», «logocentryczna», «fallocentryczna», «tyrańska»". Tak więc, jeśli dla J.S. Milla warunkiem poznania prawdy była wolność, to dla postmodernistów jest ona warunkiem wyzwolenia się od prawdy, a nawet woli jej poznania.

Skoro obiektywna prawda nie istnieje, to nie ma również jednego sposobu jej odkrywania. Oznacza to, że jest tyle prawd, ile podmiotów poznających, a w konsekwencji żadna nie jest lepsza od innej. Nadto „świat (...) jest na tyle złożony, wieloznaczny i wielopłaszczyznowy, że nie jest możliwe ujęcie jego fundamentalnych struktur w jakikolwiek system myśli’" ${ }^{70}$ Konsekwencją tego stanu rzeczy jest całkowity brak orientacji człowieka w świecie. Postmodernista nie widzi ani w sobie, ani poza sobą żadnego porządku, który mógłby stanowić dla niego punkt zaczepienia. Wszystko jest chaotycznym aglomeratem przypadkowych rzeczy. Do tego tunelu epistemologicznej niemocy nie dociera nawet promyk wiedzy czy pewności. Człowiek nie tylko nie wie, dokąd zmierza, ale czy w ogóle się porusza, a jeśli tak, to nic nie może powiedzieć o celu, do którego miałby podążać. W tym zagubieniu i osamotnieniu człowiek nie może na nikogo liczyć, a sam tylko po części jest umęczonym kowalem swojego losu. Postmodernista nie rozumie świata, który go otacza i sam nie jest przez innych rozumiany. Filozofią postmodernisty jest ciągła rezygnacja z filozofowania.

Aksjologiczna pustka staje się postulatem postmodernistycznej wizji człowieka. W postmodernizmie zanika świat wartości: nie ma wartości, dla których warto żyć lub za które warto umierać. Decyzja co do sposobu postępowania należy do jednostki, nikt inny nie jest

70 I. Z i e m iń s k i, Postmodernizm a dylematy czlowieka, Ethos 33-34/1996, s. 142; por. W. A n d r u k o w i c z, Różnorodność prawdy a zagadnienie etyki normatywnej, w: Z. S a r eło (red.), Moralność i etyka w ponowoczesności, Warszawa 1996, s. 4354. 
tym zainteresowany; dokonywane przez jednostkę wybory są jej wyłącznym problemem, ponieważ dla postmodernisty obiektywna kategoria dobra lub zła nie ma racji bytu. Nawet ,zbrodnia czy akt miłosierdzia nie będzie ani dobrem, ani złem. Aksjologicznie będzie czymś całkowicie obojętnym. Na jednakową ironię zasługuje wszystko, cokolwiek ludzie starają się czynić, cokolwiek ich w życiu dotyka". ${ }^{71}$

Postmodernistyczna filozofia i etyka są wybitnie antyspołeczne, a przeniesione na forum rodziny oznaczałyby jej koniec. ${ }^{72}$ Żadne społeczeństwo, a w szczególności rodzina nie może funkcjonować w aksjologicznie sterylnym świecie. Altruizm czy egoizm, hedonizm czy poświęcenie, wierność czy zdrada nie są dla życia rodzinnego obojętne. Dobitnie zwraca na to uwagę Jan Paweł II w encyklice Centesimus annus: „Jeżeli nie istnieje prawda transcendentna, przez posłuszeństwo której człowiek zdobywa pełną tożsamość, to nie istnieje też żadna pewna zasada, gwarantująca sprawiedliwe stosunki między ludźmi. Istotnie, ich klasowe, grupowe i narodowe korzyści nieuchronnie przeciwstawiają jednych drugim. Jeśli się nie uznaje prawdy transcendentnej, tryumfuje siła władzy i każdy dąży do maksymalnego wykorzystania dostępnych mu środków, do narzucenia własnej korzyści czy własnych poglądów, nie bacząc na prawa innych. Wówczas człowiek jest szanowany tylko na tyle, na ile można się nim posłużyć do własnych egoistycznych celów".73

\section{Postmodernistyczne postulaty edukacyjne}

Sumienie, jako norma normans, choć ostatecznie przejawia zobowiązujący charakter, ${ }^{74}$ nie jest jednak autonomicznym i wyłącznym

71 I. Z i e m i ń s k i, Postmodernizm a dylematy człowieka, s. 145.

72 Por. W. C h r o s to w s k i, Moderniści, postmoderniści i inni, Ethos 1-2/1996, s. $6 \mathrm{n}$.

73 J a n P a w e 1 II, Centesimus annus, Wrocław 2000, nr 44 (dalej: CA).

74 Por. S. R o s i k, Formowanie sumienia chrześcijańskiego w relacji do normy obiektywnej, s. 23. 
sędzią stanowienia o tym, co dobre i złe. ${ }^{75}$ Warto tę prawdę podkreślić w sytuacji, gdy nurty myśli współczesnej przyznają sumieniu jednostki wyłączny przywilej określania kryteriów dobra i zła. Każdy sam wyznacza sobie mierniki, a wobec ich powszechnej relatywności nikt nie może być pomocny innym, tym bardziej zatem nie może im niczego zalecać. ${ }^{76} \mathrm{~W}$ takim rozumieniu etyki, według której każdy człowiek staje wobec własnej prawdy, różnej od prawdy innych, punktem wyjścia przestaje być prawda obiektywna, a staje się nim prawda dla nas, jak gdyby prawda i wartości były czysto osobistymi wytworami, nie mającymi nic wspólnego z tym, co znajduje się poza nami. ${ }^{77}$

Żadna konstrukcja polityczna czy kulturalna nie może rościć sobie praw do wieczności. Dlatego Kościół żyjący w społeczeństwie nie potrzebuje żadnej władzy politycznej, aby prowadzić swoją misję. ${ }^{78}$ Tymczasem zauważa się we współczesnych czasach niepokojący trend, który przejawia się w tym, że koncepcja relatywistycznej demokracji eliminuje z polityki pojęcie dobra, tym bardziej prawdy, gdyż zagrażają one rzekomo wolności. W ostateczności nie ma innej zasady, jak werdykt większości, która wkracza w miejsce prawdy. ${ }^{79}$ Liczy się zatem nie tyle prawda obiektywna, ile raczej prawda przegłosowana, tzn. solidarnie przyjęta. Zapominając o tym, że prawda moralna nie jest ustalana według zasad i form właściwych dla rozstrzygnięć typu demokratycznego, prawdę obiektywną zastępuje się prawdą własną człowieka, prawdą subiektywną. A sumienie w subiektywizmie staje się instancją nieomylną. W ten sposób chrześ-

75 Por. VS, nr 60.

76 Por. J. R a t z i n g e r, Prawda, wartości, władza, Kraków 1999, s. 43.

77 Por. VS, nr 32; W.K. K il p a tr i c k, Psychologiczne uwiedzenie, Poznań 1997, s. 54.

78 Por. J. R a t z i n g e r, Czas przemian w Europie, Kraków 2001, s. 123; J a n P a w e 1 II, Kościół broni wolności każdego człowieka. Homilia podczas Mszy św. i koronacji figurki Matki Bożej Miłosierdzia w Santiago de Cuba (24 I 1998), OsRomPol 3/1998, nr 4.

79 Por. J. K r u c i n a, Komentarz do encykliki Jana Pawła II „Centesimus annus", w: Ja n P a w $\nmid$ II, Centesimus annus, s. 139. 
cijańska ze swej istoty teza, że postępowanie wbrew sumieniu jest zawsze grzechem, zinterpretowana została w niedopuszczalnej formie, mianowicie, że jedynym sposobem grzeszenia jest postępowanie wbrew własnemu sumieniu. ${ }^{80}$

Dziś grozi nam to, że ukryjemy prawdę pod korcem z obawy, by nie posądzono nas o brak tolerancji i pychę, albowiem wiara w istnienie prawdy czyni człowieka nietolerancyjnym. Jeśli ktoś wierzy, że poznał prawdę i chce jej bronić, to jest on - tak się mówi - nietolerancyjny wobec innych prawd.$^{81} \mathrm{Zdaniem}$ zwolenników liberalnej demokracji o takich pojęciach jak dobro i prawda nie powinno rozstrzygać żadne źródło zewnętrzne, zwłaszcza że są to pojęcia nie do udowodnienia. Tylko wolność jest dobrem, inne dobra lub prawdy wróżą nietolerancję i naruszenie demokracji. Ten, kto chce być demokratą, musi zatem przyjmować, że wszelkie poznanie jest relatywne. W tej optyce ci, którzy żywią przekonanie, że znają prawdę i zdecydowanie za nią idą, nie są z demokratycznego punktu widzenia godni zaufania, nie godzą się bowiem z tym, że o prawdzie decyduje większość. W konsekwencji chrześcijańska wiara w prawdę objawienia jawi się właściwie jako antydemokratyczna. ${ }^{82}$ Tymczasem nie ma innych prawd; istnieje tylko jedna prawda, choć wyraża się ona w formach, które noszą znamię historii, a ponadto są wytworem umysłu zranionego i osłabionego przez grzech. Tak więc ci, którzy za przekonujące $\mathrm{w}$ chrześcijaństwie uważają jedynie te treści, które zgadzają się z ich obecnymi przyzwyczajeniami, znacznie zaniżają wartość chrześcijaństwa. ${ }^{83}$

Nie trzeba wielkiego wysiłku, aby - w świetle tego, co zostało dotychczas powiedziane - dostrzec, że liberalne pojęcie demokracji

80 Por. VS, nr 113; R. O t o w i c z, ,,Veritatis splendor” w świetle Katechizmu Kościoła Katolickiego, w: E. J a n i a k (red.), W prawdzie ku wolności. W kręgu encykliki ,Veritatis splendor”, Wrocław 1994, s. 231.

81 Por. J. R a t z i n g e r, O nihilizmie, piekle i kryzysie w Kościele, Fronda 15$-16 / 1999$, s. 19.

${ }^{82}$ Por. CA, nr 46; J. R a t z i n g e r, O nihilizmie, piekle i kryzysie w Kościele, s. 7.

83 Por. FR, nr 51; J. R a t z i n g e r, Sól ziemi, Kraków 1998, s. 146. 
nieodzownie związane jest ze sceptycyzmem i relatywizmem. Ów relatywizm właśnie zdaje się gwarancją wolności. ${ }^{84} \mathrm{O}$ tym jednak, jak mocno chybione jest to wnioskowanie, można przekonać się po osiągniętych skutkach. Z relatywizmu moralnego rodzi się bowiem egoizm, podziały, marginalizacja, dyskryminacja, lęk i nieufność wobec innych. ${ }^{85}$ Przyjęcie owego prądu myślowego oznacza zarazem, że odpowiedzi na wszystkie wielkie pytania ludzkiego bytu-pytanie o sens życia, o śmierć, o Boga, a także kwestie etyczne - stają się czymś arbitralnym i dowolnym. A gdy odpowiedzi na wielkie pytania etyki są czymś dowolnym, gdy te pytania nie zyskują wspólnej odpowiedzi, człowiek znajduje się w niebezpieczeństwie. Czysta roszczeniowość jest błędną receptą na życie. Człowiek może dojrzeć i wydać owoce właśnie dzięki temu, że podporządkowuje się jakimś wymaganiom i pozwala ograniczyć własne roszczenia. ${ }^{86}$

Marek FILIPCZUK

Słowa kluczowe: wychowanie moralne, cywilizacja, antropologia chrześcijańska, prawda, wolność, sumienie, postmodernizm

Keywords: Moral education, civilization, Christian anthropology, truth, freedom, conscience, postmodernism

\section{Moral Education in the Context of Civilization Changes}

Summary

The ecclesiastical context appears to have a special importance for moral education. This is obvious as moral education is carried out in the life of a specific religious community. The second half of the $20^{\text {th }}$ century, i.e., the

${ }^{84}$ Por. J. K r u c i n a, Komentarz do encykliki Jana Pawła II „Centesimus annus", s. 138.

${ }^{85}$ Por. J a n P a w eł II, Szczęście osiaga się przez ofiarę. Homilia podczas Mszy św. na pl. Ignacio Agramonte w Camagüey (23 I 1998), OsRomPol 3/1998, nr 3.

${ }_{86}$ Por. J. R a t z i n g e r, O nihilizmie, piekle i kryzysie w Kościele, s. 7; t e n ż e, Sól ziemi, s. 145. 
period introducing us into the new millennium, has been a time of deep transformations in Christianity and particularly in the Catholic Church. Needless to say, these transformations have had a remarkable impact on the process of moral education of the young generation.

It may be said that the political, economic, social, cultural and religious changes of the $20^{\text {th }}$ century have a specific character. A symptomatic feature of these changes, observed especially nowadays, is their rapid pace as well as their universal character. Industrial civilization transformed not only people's external living conditions, but has had an influence on man's inner life and on his behaviour in both moral and religious spheres. The occurrence of these changes can be noted not only in particular nations, but indeed in the whole of mankind.

The new conditions exert an influence also on religious life. On the one hand they enhance the ability of a critical judgment and have a purifying effect on the world outlook, ridding it of magical elements and occasional superstitions which happen to darken it. On the other hand there is required a more personal and active clinging to faith, which helps many people to adopt a more vital relationship with God; many others, however, practically abandon religion. 